\title{
PENGAMATAN MORPHOLOGI OKSIDASI MIKROSTRUKTUR LAPISAN KERAK KOROSI PADA PADUAN Ni-AI
}

\author{
Sahlan \\ STT-PLN \\ e-mail: sahlan_1956@yahoo.com
}

\begin{abstract}
The impeller of air plane turbine or electrical generator gas turbine, generally used $\mathrm{Ni}$ base content superalloy. For long time turbine operation, oxidation of Ni-alloy could be happened. This research want to know the effect of the high temperature and time duration of turbine operation, especially oxidation of Ni-3Al alloy. In this research the temperature treatment at 1298 and $1498^{\circ} \mathrm{K}$, while time duration 20,25 and 50 hours. The research result shows that NiO Oxid is formed and porous crystall granulars are identified. This porous crystalls are $\mathrm{Ni}_{2} \mathrm{O}_{4}$.
\end{abstract}

Keywords: Superalloy, Ni-Al, porous crystall, NiO.

\section{PENDAHULUAN}

Nikel terutama dibuat dengan cara elektrolisa, akan tetapi bahan yang dinamakan nikel Mond dalam bentuk pellet dihasikan dengan cara pirolisa yang dibuat dari nikel karbonil. Nikel adalah logam yang berwarna perak keabu-abuan mempunyai kisi sel satuan kubus pemusatan sisi (kps) atau fcc (faced centered cubic) dengan massa jenis 8,7 yang hampir sama dengan massa jenis tembaga (Cu). Setelah penganilan, kekuatan tariknya 45 hingga $55 \mathrm{kgf} / \mathrm{mm}^{2}$, perpanjangannya $45-50 \%$, dan kekerasannya 80-90 Brinnel. Ni baik sekali untuk ketahanan panas dan ketahanan korosi atau oksidasi, dan tidak rusak oleh air kali atau air laut dan alkali, tetapi tidak tahan atau rusak oleh asam nitrat dan sedikit tahan korosi terhadap asam khlor dan asam sulfat.

Nikel dipadu dengan unsur $\mathrm{Al}$ dari 0,1 hingga $3,0 \%$ membentuk paduan larutan padat- $\gamma$ ( $\gamma$-solid solution alloys) yang sangat stabil dan dipadu dengan beberapa unsur lainnya dapat dipergunakan sebagai bahan yang mempunyai ketahan mulur pada suhu tinggi (creeping) dan tahan oksidasi. Kecepatan kinetisitas oksidasi, komposisi dan struktur kerak dan lapisan kerak bawah (subscale) yang terbentuk pada fasa larutan padat $\mathrm{Ni}$-Al pada umumnya membetuk lapisan kerak berlapis ganda (multilayered) $\mathrm{NiO} / \mathrm{NiAl}_{2} \mathrm{O}_{4} / \mathrm{Al}_{2} \mathrm{O} 3$. Pada tulisan ini akan menguraikan secara rinci hasil pengamatan kecepatan kinetisitas kerak dan larutan dari pada morphologi kerak dan lapisan kerak paduan nikel dengan paduan aluminum sampai dengan $6 \mathrm{wt} \%$ pada kondisi kerja antara 1273 dan $1473^{\circ} \mathrm{K}$.

Prinsip dasarnya, kinetisitas oksidasi untuk nikel dan paduannya pada interval waktu selama 2 hari dalam lingkungan udara pada suhu antara 1298 dan $1498{ }^{\circ} \mathrm{K}$ akan terbentuk parabola oksidasi nikel. Paduan yang mengandung sampai dengan 3 wt\% $\mathrm{Al}$ menunjukkan tampilan bentuk parabola yang lebih mencolok dibandingkan dengan oksidasi nikel. Untuk paduan $\mathrm{Ni}-2 \mathrm{Al}$, pertumbuhan lapisan individual $\mathrm{NiO}$ dan $\mathrm{NiO}+\mathrm{NiAl}_{2} \mathrm{O}_{4}$ dalam penetrasi kerak dan lapisan kerak berbentuk parabola, dan kinetisitas oksidasi paduan $\mathrm{Ni}-6 \mathrm{Al}$ akan menghasilkan pertumbuhan bintik-bintik halus (nodules) dimana dalam susunannya diikuti reaksi dengan periode transisi panjang dan berlangsung terus-menerus dan kemudian menurun saat sampai pada puncak terbentuknya larutan kerak $\mathrm{NiO} / \mathrm{NiAl}_{2} \mathrm{O}_{4} / \mathrm{Al}_{2} \mathrm{O} 3$.

\section{STUDI PUSTAKA}

Pada prinsip dasarnya untuk aluminium yang terlarut (solvent) dalam paduan nikel (solute) dan kemudian terbentuk oksida $\mathrm{NiO}$ pada permukaannya maka fenomena yang terjadi adalah difusi nikel akan berjalan kearah 
keluar (outward) lapisan permukaan yang kemudian menjangkau lapisan eksternal $\mathrm{NiO}$ dan besarnya peningkatan pertumbuhan rataratanya bergantung pada kandungan paduan aluminumnya yang terlarut oleh peningkatan dalam konsentrasi kekosongan atau vakansi dan difusi nikel dalam Ni dari doping aluminum yang memenuhi persamaan:

$$
\mathrm{Al}_{2} \mathrm{O}_{3}=2 \mathrm{Al} \mathrm{Ni}_{\mathrm{Ni}}^{\bullet}+\mathrm{V}_{\mathrm{Ni}}^{\prime \prime}+3 \mathrm{O}_{\mathrm{O}}^{x}
$$

dimana $A l_{N i}^{\bullet}, V_{N i}^{\prime \prime}$ dan $O_{N i}^{\prime \prime}$ mengacu pada banyaknya aluminum dalam larutan nikel, vakansi kation dan oksigen dalam larutan oksigen dalam NiO yang terbentuk. Pengaruh doping kebanyakan mempengaruhi prosentase berat paduan yaitu sekitar $0,1 \mathrm{wt} \% \mathrm{Al}$, sebab ini dibatasi oleh sayarat keseimbangan paduan $-\mathrm{NiAl}_{2} \mathrm{O}_{4}-\mathrm{NiO}$ pada aktivitas permukaan paduan aluminum dan sebab lain yaitu fraksi $\mathrm{NiAl}_{2} \mathrm{O}_{4}$ yang lebih besar serta adanya porositas (pori-pori) didalam lapisan pada dua fasa pada paduan yang lebih kaya dalam aluminum yang terlarut dan kemudian menurun pada areal terak (flux) nikel. Oksigen yang ada didalam pertumbuhan $\mathrm{Al}_{2} \mathrm{O}_{3}$ berfungsi sebagai partikel kecil, penguhubung pada sisi muka oksidasi sebelah dalam (internal) dan meningkat setelah terbentuknya $\mathrm{NiO}$, yang mempunyai persamaan reaksi:

$$
\begin{aligned}
& 3 \mathrm{NiO}_{(\text {kerak })}+2 \mathrm{Al}_{\text {(paduan) }} \\
& 3 \mathrm{Ni}_{\text {(kerak) }} \ldots \ldots \ldots \ldots \ldots \ldots(2)
\end{aligned}
$$

dimana dampak langsung dari pada difusi nikel terhadap kerak adalah aluminum bereaksi langsung dengan oksigen (udara) atmosphere. Ini dapat dipahami bahwa terbentuknya penetrasi parabolis arah masuk kedalam zona oksidasi internal menuju paduan $\mathrm{Ni}-2 \mathrm{Al}$ dikontrol oleh difusi oksigen. Pengkayakan reaksi $\mathrm{Al}_{2} \mathrm{O}_{3}$ antara nikel dan oksigen didalam paduan diantara sisi dalamnya dengan zona oksidasi internal yang diesebabkan adanya pertumbuhan $\mathrm{NiAl}_{2} \mathrm{O}_{4}$ dalam bentuk persenyawaan:

$$
\mathrm{NiAl}_{2} \mathrm{O}_{4 \text { (paduan) }} \mathrm{Ni}_{\text {(paduan) }}+\mathrm{O}_{\text {(paduan) }}+\mathrm{Al}_{2} \mathrm{O}_{3 \text { (paduan) }}=
$$

Beberapa pertumbuhan arah keluar dari pada $\mathrm{NiAl}_{2} \mathrm{O}_{4}$ kearah lapisan oksida sisi dalam terjadi selama adanya perputaran difusi aluminum dan nikel didalam difusi $\mathrm{NiO} / \mathrm{Al}_{2} \mathrm{O}_{3}$ yang kemudian mendorong untuk lebih meningkatkan pertumbuhan $\mathrm{NiAl}_{2} \mathrm{O}_{4}$. Oleh karena itu, difusi aluminum yang langsung menyusup kedalam $\mathrm{NiAl}_{2} \mathrm{O}_{4}$ membentuk persenyawaan reaksi;

$$
2 \mathrm{Al}_{\left.\left(\mathrm{Al}_{2} \mathrm{O}_{3}\right)\right)}+4 \mathrm{NiO}_{(\mathrm{ker} a k)}=\mathrm{NiAl}_{2} \mathrm{O}_{4(\mathrm{ker} a k)}+3 \mathrm{Ni}_{(\mathrm{ker} a k)}
$$

yang kemudian menyebabkan pertumbuhannya berkembang keluar dan menggeser kedudukan $\mathrm{Ni}$ dalam bentuk difusi langsung kedalam lapisan $\mathrm{NiO}$. $\mathrm{NiAl}_{2} \mathrm{O}_{4}$ dan mendukung kedalam gradient aluminum selama komposisinya pada suhu $1273^{\circ} \mathrm{K}$ yang mana ini akan diketahui dari harga stoikiometri pada $\mathrm{NiO} 1,27 \quad \mathrm{Al}_{2} \mathrm{O}_{4}-\mathrm{Al}_{2} \mathrm{O}_{3}$ yaitu antara batas tekanan oksigen yang berbanding terhadap paduan $-\mathrm{NiAl}_{2} \mathrm{O}_{4}-\mathrm{NiO}$ dan paduan $-\mathrm{NiAl}_{2} \mathrm{O}_{4}$ $\mathrm{Al}_{2} \mathrm{O}_{3}$ satu sumbu.

Mekanisme untuk transisi dari pertumbuhan kerak dan pertumbuhan lapisan dibawah kerak (subscale) ke pertumbuhan berikutnya yang kemudian membentuk kerak lapisan luar berikutnya pada kandungan aluminum yang lebih besar. Pertumbuhan lateral pada lapisan film $\mathrm{Al}_{2} \mathrm{O}_{3}$ yang terjadi pada oksidasi internal didepan dari pengendapan $\mathrm{Al}_{2} \mathrm{O}_{3}$ sepanjang batas butiran paduan dan pada sisi pembatas untuk difusi aluminum dan oksigen yang disebabkan oleh alur-alur $\mathrm{Al}_{2} \mathrm{O}_{3}$ dalam matrik paduan. Pengembangan sempurna pada lapisan film $\mathrm{Al}_{2} \mathrm{O}_{3}$ yang tidak beraturan oleh dua moda diatas terakhir yang terisolasi didalam zona oksidasi internal dari lapisan kerak bawah paduan. Berkenaan dengan itu, konversi nikel didalam zona oksidasi internal yang terisolasi oleh proses difusi menjadi $\mathrm{NiO}$ dan $\mathrm{NiAl}_{2} \mathrm{O}_{4}$ yang nyatanya dihasilkan didalam pertumbuhan kerak - $\mathrm{NiO} / \mathrm{NiAl}_{2} \mathrm{O}_{4} / \mathrm{Al}_{2} \mathrm{O}_{3}$.

Mekanisme oksidasi ini konsisten dengan teori dasar thermodinamika system Ni-Al-O. Diagram keseimbangan tekanan oksigen pada suhu $1273{ }^{\circ} \mathrm{K}$ seperti pada Gambar 1 menunjukkan keseimbangan $\mathrm{Al}_{2} \mathrm{O}_{3}$ didalam paduan utama $\mathrm{Ni}$-Al mencakup perpaduan untuk semua komposisi, sebab koeksistensi paduan $-\mathrm{NiAl}_{2} \mathrm{O}_{4}-\mathrm{Al}_{3} \mathrm{O}_{3}$ stabil pada kurang dari $1 \mathrm{ppm}$ Al. Oleh karena itu suatu gradient oksigen akan muncul pada kerak duplek arah melintangnya pada daerah suhu ini dari tekanan atmosphere sampai dengan $P_{\mathrm{O}_{2}}=3,8$ x $10^{-11}$ atm. Untuk koeksistensi pada paduan $-\mathrm{NiAl}_{2} \mathrm{O}_{4}-\mathrm{NiO}$, maka penyusutan $\mathrm{NiO}$ dari koeksistensi ini akan mensuplai oksigen ke 
dalam paduan. Formasi $\mathrm{NiAl}_{2} \mathrm{O}_{4}$ pada persamaan (3) memberikan peluang membentuk pertumbuhan lebih lanjut menjadi zona oksidasi internal sebagai bentuk isolasi terjadinya pengendapan atau pengembangan jalur-jalur $\mathrm{NiAl}_{2} \mathrm{O}_{4}$ untuk selanjutnya mengendap pada daerah tekanan oksigen dari $3,8 \times 10^{-11}$ sampai dengan $4,9 \times 10^{-13} \mathrm{~atm}$. $\mathrm{Al}_{2} \mathrm{O}_{3}$ oksida internal manjadi stabil pada tekan oksigen yang lebih rendah yang menurunnya akan berhenti dengan adanya tanda batas stabil fasa larutan padat $\gamma \mathrm{Ni}-\mathrm{Al}$ dari $P_{\mathrm{O}_{2}}=4,9$ $\times 10^{-13}$ atm., sampai pada batas dibawah $P_{\mathrm{O}_{2}}=$ $6,0 \times 10^{-12} \mathrm{~atm}$.

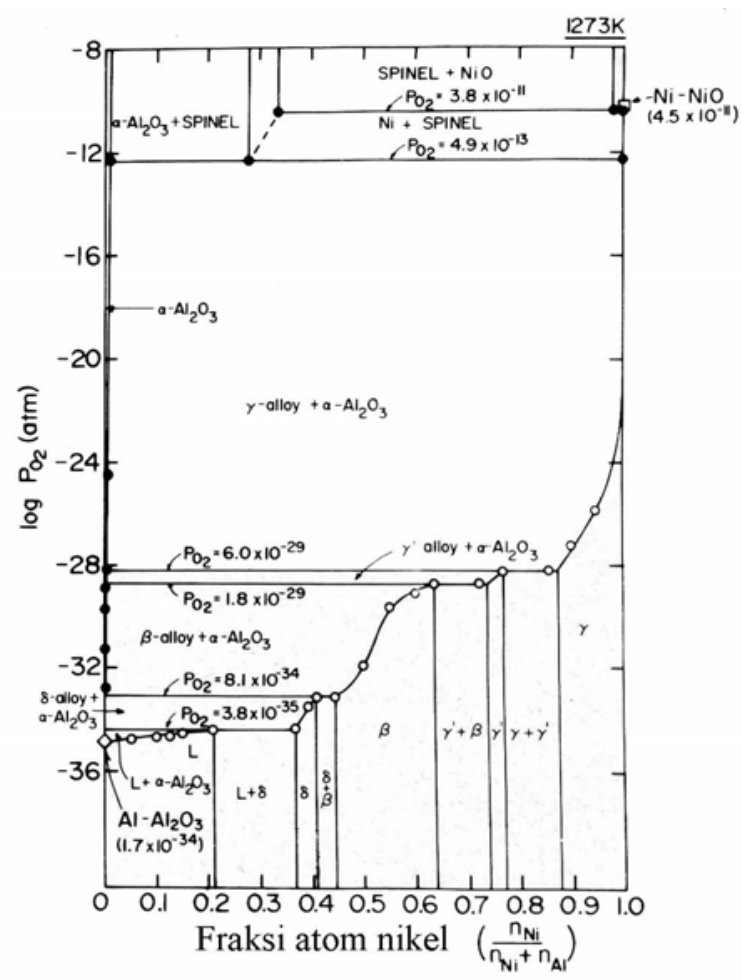

Gambar 1. Diagram keseimbangan tekanan oksigen untuk system $\mathrm{Ni}-\mathrm{Al}-\mathrm{O}$ pada suhu $1273^{\circ} \mathrm{K}$

Spesies atau koloni difusi predominan selama pertumbuhan kerak dan kerak lapisan bawah ada nikel didalam kerak, dan oksigen dalam paduan dari pada zona kerak lapisan bawah. Satu hal yang tdak dapat diabaikan adalah proses difusi yang diikuti dengan lapisan kerak dalam $\mathrm{NiO}+\mathrm{NiAl}_{2} \mathrm{O}_{4}$, yaitu adanya pengurangan jumlah $\mathrm{NiO}$ pada permukaan paduan mengatur fluks oksigen arah keluar dan arah masuk, dan adanya pengurangan jarak antara jalur-jalur $\mathrm{NiAl}_{2} \mathrm{O}_{4}$ seperti pada Gambar 2, menunjukkan bahwa $\mathrm{NiO}$ ketidak kesempurnaan kontak dengan permukaan paduan yang saling terkait akibat adanya deformasi plastis. Akibtnya adalah pnegurangan atau penurunan $\mathrm{NiO}$ akan menyebar merata dan mengatur atau mengkontrol perpindahan molecular oksigen melintasi daerah terlarang didalam NiO$\mathrm{NiAl}_{2} \mathrm{O}_{4}$. Dan yang terakhir tidak dapat dirumuskan pada tingkat relative pertumbuhan arah masuk $\mathrm{NiAl}_{2} \mathrm{O}_{4}$ oleh adanya difusi oksigen didalam paduan, persamaan (3), dan pertumbuhannya arah keluar oleh difusi aluminum dalam $\mathrm{NiAl}_{2} \mathrm{O}_{4}$, persamaan (4).

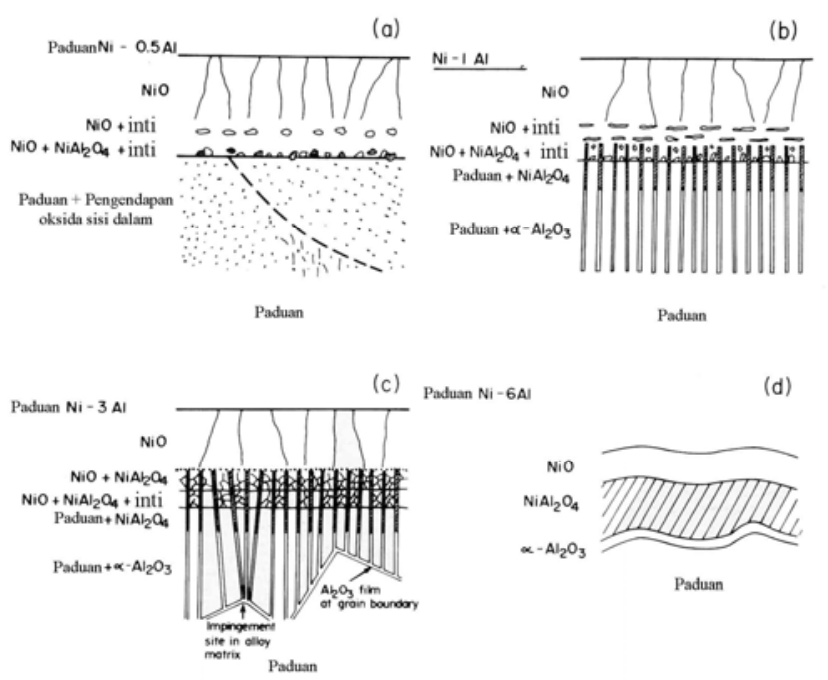

Gambar 2. Model skematis untuk pertumbuhan kerak dan kerak lapisan bawah pada paduan larutan padat $\gamma$ (a). Kerak $\mathrm{NiO}$ yang mengandung $\mathrm{NiAl}_{2} \mathrm{O}_{4}$

(b). Kerak duplek yang mengandung sisi lapisan luar $\mathrm{NiO}+$ dan sisi lapisan dalam $\mathrm{NiO}+\mathrm{NiAl}_{2} \mathrm{O}_{4}$

(c). Kerak dan kerak lapisan bawah paduanNi-3 Al yang membentuk film $\mathrm{Al}_{2} \mathrm{O}_{3}$ yang terputus-putus pada muka oksidasi internal

(d). Pengembangan penuh kerak $\mathrm{NiO} / \mathrm{NiAl}_{2} \mathrm{O}_{4} / \mathrm{Al}_{2} \mathrm{O}_{3}$ pada paduan $\mathrm{Ni}-6 \mathrm{Al}$

\section{METODOLOGI PENELITIAN}

Dalam pengamatan morphologi oksidasi paduan $\mathrm{Ni}-3 \mathrm{Al}$ yang menggunakan analisis EDAX, pertama kali yang dilakukan adalah menyiapkan benda uji (specimen) dari bahan paduan 0,$1 ; 0,5 ; 1,0 ; 2,1$; dan $3,0 \mathrm{wt} \% \mathrm{Al}$, dimana masing-masing dibuat dalam bentuk lembaran (plat) tipis dengan ukuran panjang, lebar dan tebal masing-masing adalah $2 \mathrm{~cm}$, $2 \mathrm{~cm}$ dan $1 \mathrm{~cm}$. Kemudian dilakukan preparasi dengan penyelesaian akhirnya (finishing) dengan penghalusan permukaan logam (metallographically polished) menggunakan pasta batu intan (diamond paste) dengan kehalusan $1 \mu \mathrm{m}$. Untuk pengamatan oksidasi permukaan pada benda uji menggunakan gravimetris kinetis, yaitu suatu cara atau metoda pengamatan atau pengukuran oksidasi permukaan dengan memasukkan 
benda uji dalam satu ruangan tertutup dan dialiri gas oksigen pada tekanan udara tetap 1 atmosphere, kemudian dilakukan pengamatan untuk menentukan komposisi, struktur dan morphologinya.

\section{HASIL DAN PEMBAHASAN}

Dari hasil pengamatan untuk mengamati saat pertama kali terbentuk lapisan $\mathrm{NiO}$ pada permukaan nikel, teramati adanya permulaan awal terbentuknya butiran-butiran, dan akan terus tumbuh atau berkembang menjadi butiran-butiran besar (columnar) yang kemudian menjadi butiran sempurna pada suhu $1498{ }^{\circ} \mathrm{K}$. Perilaku ini dapat dilihat pada Gambar 3 dimana pada potongan melintang terlihat adanya retakan kerak $\mathrm{NiO}$ yang terbentuk dalam tekanan 1 atmosphere udara.

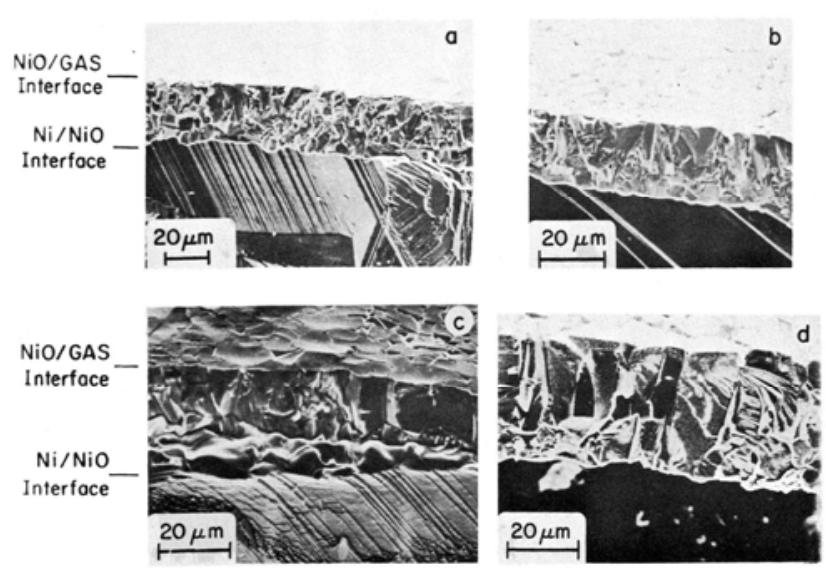

Gambar 3. Penampang melintang retakan akibat terbentuknya kerak $\mathrm{NiO}$ pada $\mathrm{Ni}$

a). 25 jam pada suhu $1298^{\circ} \mathrm{K}, 1 \mathrm{~atm}$ udara

b). 50 jam pada suhu $1298^{\circ} \mathrm{K}, 1 \mathrm{~atm}$ udara

c). 1 jam pada suhu $1498^{\circ} \mathrm{K}, 1 \mathrm{~atm}$ udara

d). 10 jam pada suhu $1498{ }^{\circ} \mathrm{K}, 1 \mathrm{~atm}$ udara

Pada Gambar 4 memperlihatkan suatu keadaan dimana suatu paduan $\mathrm{Ni}-0,1$ dan $\mathrm{Al}-$
0,5 terjadi pembentukan morphologi senyawa oksida yang sama pada daerah atau areal sisi dalamnya dan menunjukkan bentuk sisi oksida yang berpori-pori (porositas), yang tidak lain adalah sisi kolumnar kerak dan pengendapan oksida yang lembut dan acak tersebar dalam matrik paduan pada batas butiran di zona oksidasi sisi dalamnya. Oksida kolumnar itu tidak lain adalah $\mathrm{NiO}$ dan beberapa kristal dalam daerah oksida yang berpori-pori itu. Dan dengan analisis yang menggunaan EDAX dapat di identifikasikan sebagai $\mathrm{NiAl}_{2} \mathrm{O}_{4}$. Namun disini samar-samar teramati adanya komposisi dan struktur pengendapan oksida internal yang sangat lembut dan sangat sulit untuk ditentukan.

Oksidasi pada paduan $\mathrm{Ni}-1$ dan 2-Al yang mengatur pertumbuhan kerak berganda (duplex) dan lapisan kerak sisi dalam (subscale) seperti yang diilustrasikan pada Gambar 5, dimana tampilannya mencitrakan suatu keadaan lapisan $\mathrm{NiO}$ kolumnar eksternal. Berturut-turut Gambar 5(a), (b), dan (c) menunjukkan lapisan senyawa oksidasi $\mathrm{NiO}+\mathrm{NiAl}_{2} \mathrm{O}_{4}$ pada sisi dalamnya, dan juga pada Gambar 5(d) dan (e), serta terjadinya pengendapan internal $\mathrm{NiAl}_{2} \mathrm{O}_{4}-\mathrm{Al}_{2} \mathrm{O}_{3}$ pada Gambar 5(f) dan (g). Lapisan oksida internal berlumba-lumba memancang dan memagari diri seperti adanya pertumbuhan batang atau cabang $\mathrm{NiAl}_{2} \mathrm{O}_{4}$ dan kemudian berkembang terus membentuk $\mathrm{NiO}$ sebagai kelanjutan pengendapan oksida internal pada tahap berikutnya. Derajat porositas atau pori-pori yang terdekat dalam lapisan ini dan yang paling luas jangkauannya adalah untuk paduan Ni-2 Al, dimana pada pengendapan oksida internal ditandai dengan adanya bidang melintang yang merupakan zona oksidasi internal atau sebagai zona batang silindris, namun yang berada dibawah $\mathrm{NiAl}_{2} \mathrm{O}_{4}$ kearah sisi atas $\mathrm{Al}_{2} \mathrm{O}_{3}$ tidak teramati.
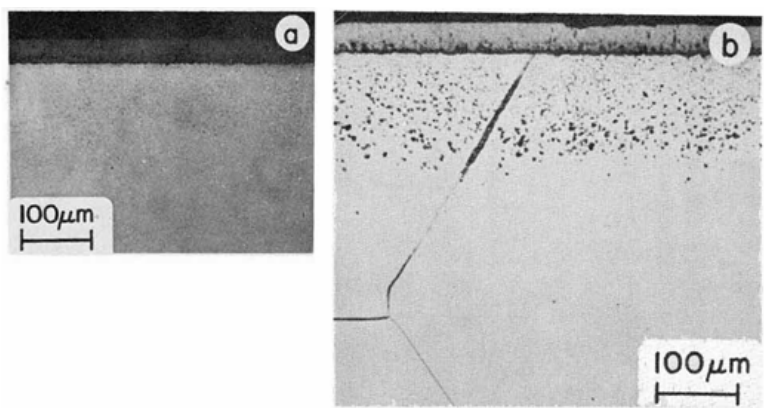
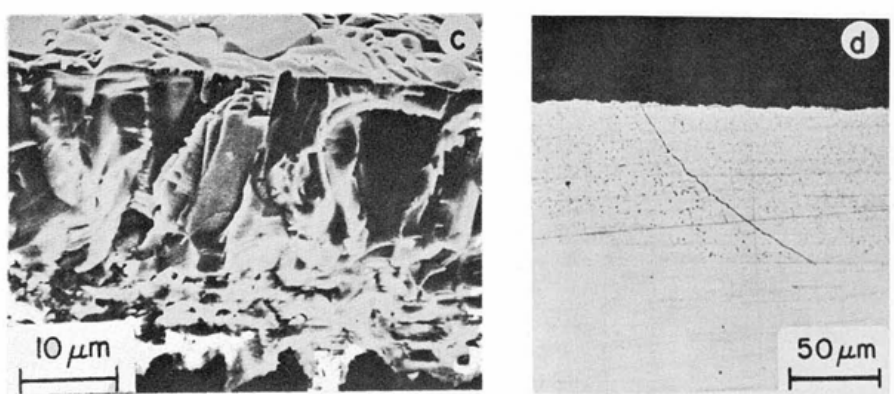

Gambar 4. Penampang melintang metalografi dan retakan zona oksidasi internal dan kerak dari pada paduan $\mathrm{Ni}$-Al pada suhu $1298^{\circ} \mathrm{K}$ untuk paduan $\mathrm{Ni}-0,1 \mathrm{Al}$

(a). Tidak dietsa; (b). Dietsa: paduan Ni-05 Al; (c) Penampang retakan; (d) Tidak dietsa 

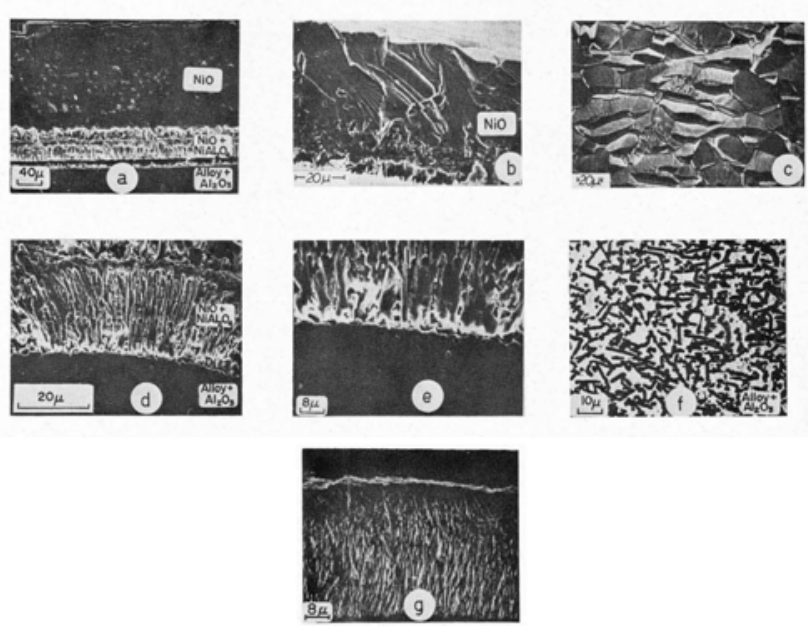

Gambar 5: Struktur oksidasi paduan Ni-2Al pada suhu 1473 (1 atm udara), kecuali (g).

(a). Penampang melintang global, (b) lapisan $\mathrm{NiO}$ sisi luar, (c). permukaan kerak eksternal, (d) lapisan dalam $\mathrm{NiO}+\mathrm{NiAl},(\mathrm{e})$ antar sisi lapisan dalam dan zona oksidasi internal, (f) zona oksidasi internal, (g) zona oksidasi internal bagian bawah yang dietsa dengan larutan iodinemethanol.

Morphologi oksida pada dan didalam paduan $\mathrm{Ni}-3 \mathrm{Al}$ ada kemiripan atau kesamaan seperti yang diatas terkecuali untuk dua fasa lapisan dalam kerak yang porositasnya lebih mencolok terutama didalam zona kerak yang lebih dalam pada larutan parsial film $\mathrm{Al}_{2} \mathrm{O}_{3}$ yang ada di muka oksidasi internal pada suhu $1273^{\circ} \mathrm{K}$. Gambar 6 menunjukkan citra morphologi kerak dan kerak lapisan dalam pada paduan Ni-3 Al yang teroksidasi pada tekanan $1 \mathrm{~atm}$. Udara yang diamati dengan difraksi sinar- $X$ ada beberapa citra variasi sisi dalam yang berbeda-beda. Kandungan kerak pada lapisan $\mathrm{NiO}$ kolumnar eksternal (Gambar 6a), menunjukkan adanya lapisan oksidasi yang saling tumpang tindih pada daerah batang $\mathrm{NiAl}_{2} \mathrm{O} 4$ yang kompak, dimana $\mathrm{NiO}$ dalam matrik batang $\mathrm{NiAl}_{2} \mathrm{O}_{4}$ ini mengandung daerah yang berpori-pori lebih dalam dan lebih rapat jarak penetrasi dari beberapa $\mathrm{NiO}$ sebagai butiran-butiran antara kedua batang ini (Gambar 6a dan 6b). Bagian film $\mathrm{Al}_{2} \mathrm{O}_{3}$ pada sisi depan akibat dari reaksi internal yang dikembangkan oleh dua keadaan yang berbeda, yaitu keadaan dimana pertumbuhan film dari adanya pengendapan $\mathrm{Al}_{2} \mathrm{O}_{3}$ yang orientasinya mendekati batas butiran paduan untuk memblokir pertumbuhan yang mengarah masuk kedalm dari pada pengendapan batang (Gambar 6c), dan yang kedua pada keadaan batang $\mathrm{Al}_{2} \mathrm{O}_{3}$ bereaksi dengan matrik paduan (Gambar $6 \mathrm{~d}$ ). Pencitraan difraksi sinar-X yang termaktup dalam Gambar 6 menggambarkan bahwa perkembangan $\mathrm{NiAl}_{2} \mathrm{O}_{4}$ merupakan bagian dari ujung batang $\mathrm{Al}_{2} \mathrm{O}_{3}$ yang mengarah sisi dalam yaitu dengan kedalaman sekitar $50 \mu \mathrm{m}$ ke paduan ini.

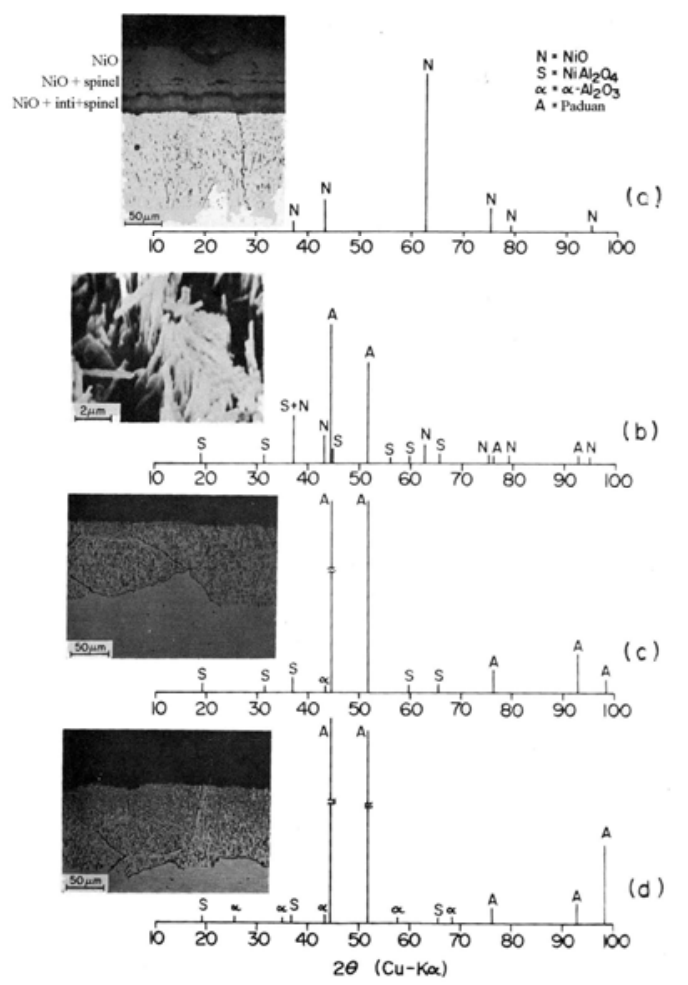

Gambar 6. Morphologi kerak dan lapisan dalam paduan Ni-3 Al yang teroksidasi pada $1 \mathrm{~atm}$ tekanan udara.

(a). penampang melintang metalografi, (b). Pori-pori sisi dalam lapisan $\mathrm{NiO}+\mathrm{Al}_{2} \mathrm{O}_{4}$ dari pandangan atas, (c). Film oksida $\mathrm{Al}_{2} \mathrm{O}_{3}$ pada batas butiran paduan dimuka oksidasi internal, (d) Film oksida $\mathrm{Al}_{2} \mathrm{O}_{3}$ dalam matrik paduan pada sisi muka oksidasi internal.

Kerak pada paduan Ni-6 Al (Gambar 7) merupakan pengembangan dari nodul $\mathrm{NiO}+\mathrm{NiAl}_{2} \mathrm{O}_{4}$ yang mana perkembangannya lateral dan vertical dari arah proyeksi dalam film lapisan tipis $\mathrm{Al}_{2} \mathrm{O}_{3}$ pada permukaan paduan yang dipoles. Kerak dan lapisan dalam kerak yang terbentuk dari awal (Gambar 7a) menunjukkan gambar morphologi untuk paduan Ni-3 Al. Dalam kasus ini, walaupun ada pertumbuhan lateral pada sisi permukaan film $\mathrm{Al}_{2} \mathrm{O}_{3}$ dari reaksi awalnya (Gambar $7 \mathrm{~b}$ ) namun muncul suatu keadaan baru pada permukaan yang terisolasi kerak oksida penumpu nikel dan kerak lapisan dalam dari paduan. Oksida ini ditransformasi dan kemudian mempertebal lapisan dalamnya sampai melewati batas waktu oksidasi transien yang lama sampai pada batas waktu 150 jam pada suhu $1473{ }^{\circ} \mathrm{K}$ dan akhirnya membentuk kerak $\mathrm{NiO} / \mathrm{NiAl}_{2} \mathrm{O}_{4} / \mathrm{Al}_{2} \mathrm{O}_{3}$ (Gambar $5 \mathrm{c}$ ). 


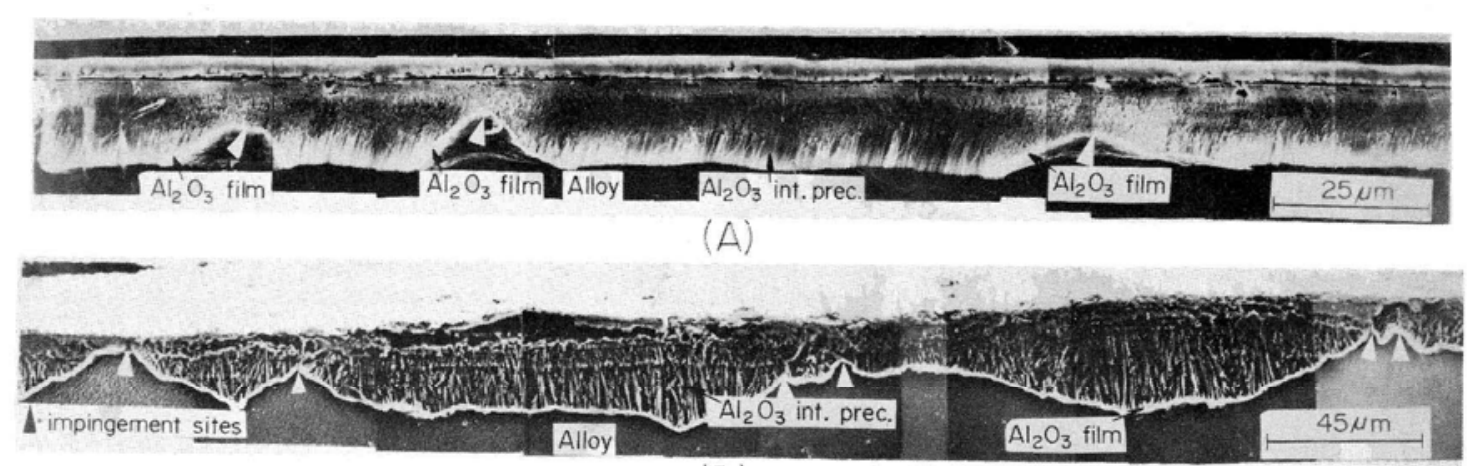

(B)

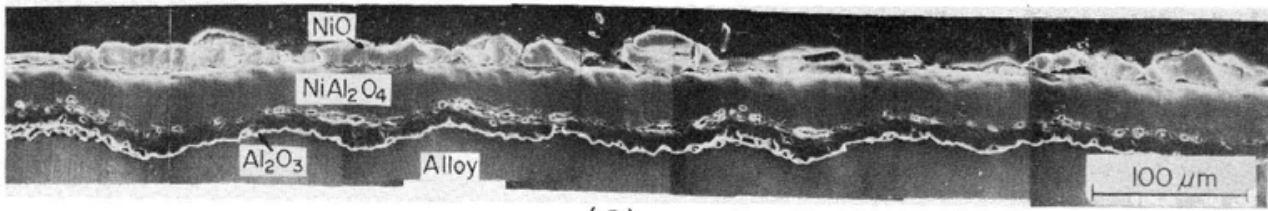

(C)

Gambar 7. Morphologi kerak dan lapisan kerak dalam paduan Ni-6Al yang terosidasi pada tekanan 1 atm udara, suhu $1373^{\circ} \mathrm{K}$ setelah dietsa dengan larutan iodine-methanol

(a).zona pengendapan oksida internal dan terputusnya lapisan film $\mathrm{Al}_{2} \mathrm{O}$ pada sisimuka oksidasi, (b) Formasi film $\mathrm{Al}_{2} \mathrm{O}_{3}$ yang tidak terputus pada sisi muka oksidasi internal, (c). kerak yang seluruhnya terlapisi larutan $\mathrm{NiO} / \mathrm{NiAl}_{2} \mathrm{O}_{4} / \mathrm{Al}_{2} \mathrm{O}_{3}$

\section{LINTASAN DIFUSI}

Paduan Ni-Al, $\leq 3$ wt\% Al yang teroksidasi parabolis dan akan lebih cepat lagi terjadi pada kandungan aluminum yang lebih besar serta akan meningkat dalam harga kisaran rata-rata reaksi. Pada Tabel 1 dapat dilihat bahwa untuk kandungan aluminum sampai dengan $0,1 \mathrm{wt} \%$, kinetisitas oksidasi pada paduan Ni-6 Al menjadi tidak beraturan dan besaranya akan menurun menjadi lebih kecil selama terjadi pengembangan pelapisan kerak $\mathrm{NiO} / \mathrm{NiAl}_{2} \mathrm{O}_{4} / \mathrm{Al}_{2} \mathrm{O}_{4}$. Oksidasi dari pada nikel akan mengatur pertumbuahn kerak $\mathrm{NiO}$, dimana batasan butiran bidang meratanya terbentuk sejak awal untuk menjadi butiran kolumnar yang lebih luas. Selama pertumbuh kerak, disini terjadi difusi logam yang predominan dimana harga rata-rata oksidasinya adalah tetap bilamana nantinya dihitung dengan menggunakan persamaan Wagner atau menggunakan harga difusi mandiri (self-difusion) nikel dalam kristal tunggal NiO. Konstanta harga rata-rata eskperimental nikel kemurnian tinggi lebih besar dari pada harga rata-rata hasil perhitungan oleh factor $\leq 2$ seperti pada Tabel 1 , dan kemudian besarnya harga rata-rata oksidasi awalnya menjadi makin besar dan ini merupakan penggabungan antara harga kontribusi difusi sambungan singkat dengan harga lintasan difusi.
Model skematis yang menampilkan pertumbuhan lapisan oksida pada paduan seperti yang ditunjukkan dalam Gambar 2, yang paling banyak memaparkan bentuk citra pertumbuhan kerak yang merupakan lapisan $\mathrm{NiO}$ kolumar eksternal dan lapisan dalam $\mathrm{NiAl}_{2} \mathrm{O}_{4}$, dan pertumbuhan lapisan kerak dalam $\mathrm{NiAl}_{2} \mathrm{O}_{4}+\mathrm{Al}_{2} \mathrm{O}_{3}$ dengan morphologi yang berbeda, serta yang terakhir adanya transisi dari pada pertumbuhan kerak $\mathrm{Nio} / \mathrm{NiAl}_{2} \mathrm{O}_{4} / \mathrm{Al}_{2} \mathrm{O}_{3}$ yang dihasilkan dari pertumbuhan lateral film oksidasi $\mathrm{Al}_{2} \mathrm{O}_{3}$ internal sisi muka dalam paduan yang mengandung alumunium yang lebih besar. Pertumbuhan lapisan oksida dan pengendapannya diatur atau ditentukan oleh mekanisme difusi dibawah ketentuan atau batasan thermodinamis.

Mekanisme lintasan difusi adalah satu kosistensi kita untuk memahami perilaku paduan yang mengandung $\leq 2 \mathrm{wt} \%$ Al. Seperti pada Ganbar 2a dan 2b, selama pertumbuhan lapisan $\mathrm{NiO}$ eksternal mencakup pada difusi nikel arah keluar maka peningkatan didalam pertumbuhan rata-rata ini dengan kandungan paduan aluminum terbawa oleh adanya peningkatan dalam konsentrasi kekosongan dan kemudian difusi nikel dalam $\mathrm{NiO}$ dari adanya doping yang berhubungan dengan reaksi pada persamaan (1). 


\section{KESIMPULAN}

Dalam pengamatan morpologi aksidasi paduan $\mathrm{Ni}-3 \mathrm{Al}$ yang menggunakan analisis EDAX disini setelah benda uji diperlakukan proses sintering pada suhu 1298 dan $1498 \mathrm{~K}$ dengan variasi waktu masing-masing 10, 25, dan 50 jam, pada tekanan 1 atmosphere udara, menunjukkan adanya kesamaan, yaitu terbentuknya oksida kolumnar $\mathrm{NiO}$ dan beberapa butiran kristal dalam daerah oksida yang berpori-pori yang teridentifikasi sebagai $\mathrm{NiAl}_{2} \mathrm{O}_{4}$ yang mana secara mikrostruktur menunjukkan komposisi dan struktur pengendapan oksida internal yang sangat halus.

Kandungan kerak pada lapisan $\mathrm{NiO}$ kolumnar eksternal menunjukkan adanya lapisan oksidasi yang saling tumpang tindih pada daerah batang $\mathrm{NiAl}_{2} \mathrm{O} 4$ yang kompak, dimana $\mathrm{NiO}$ dalam matrik batang $\mathrm{NiAl}_{2} \mathrm{O}_{4}$ ini mengandung daerah yang berpori-pori lebih dalam dan lebih rapat jarak penetrasi dari beberapa $\mathrm{NiO}$ sebagai butiran-butiran antara kedua batang ini.
Kerak pada paduan Ni-6 Al merupakan pengembangan dari nodul $\mathrm{NiO}+\mathrm{NiAl}_{2} \mathrm{O}_{4}$ yang mana perkembangannya lateral dan vertical dari arah proyeksi dalam film lapisan tipis $\mathrm{Al}_{2} \mathrm{O}_{3}$ pada permukaan paduan yang dipoles. Kerak dan lapisan dalam kerak yang terbentuk dari awalnya menunjukkan gambar morphologi untuk paduan Ni-3 Al. Dalam kasus ini, walaupun ada pertumbuhan lateral pada sisi permukaan film $\mathrm{Al}_{2} \mathrm{O}_{3}$ dari reaksi awalnya namun muncul suatu keadaan baru pada permukaan yang terisolasi kerak oksida penumpu nikel dan kerak lapisan dalam dari paduan.

\section{DAFTAR PUSTAKA}

Tata Surdia dan Saito Shinroku. (2003). Pengetahuan Bahan, Pt. Pradnya Paramita, Jakarta.

Sins, Chester T., Stoloff, Norman S., dan Hagel, Wikkiam C. (2001). Superalloys II: High-Temperatuter Materials For Aerospace and Industrial Power, John Wiley \& Sons, New York.

Wolf, J. S., dan Evans, E. B. (1999). Corosion, vol.18 p.129.

Hagel, W. C. (2002). Corrosion, vol 23 p 312. 